\title{
A Review of Tourism Research in the Polar Regions
}

\author{
E.J. STEWART, ${ }^{1,2}$ D. DRAPER ${ }^{1}$ and M.E. JOHNSTON ${ }^{3}$
}

(Received 26 July 2004; accepted in revised form 12 May 2005)

\begin{abstract}
Polar travel has grown dramatically in the last two decades and in recent years has become the focus of academic inquiry. Using a model initially developed for understanding the nature of culture, action, and knowledge in the development of human geography, we explore the nature, scale, and scope of research related to tourism in the Arctic and the Antarctic. We take a comparative approach to highlight the tourism issues that are largely similar in the two polar regions. Polar tourism research appears to cluster around four main areas: tourism patterns, tourism impacts, tourism policy and management, and tourism development. By assessing these emerging research clusters, we identify research gaps and potentially fruitful lines of inquiry.
\end{abstract}

Key words: tourism, tourists, polar tourism research, Arctic, Antarctica, social science research

RÉSUMÉ. Ces vingt dernières années, les voyages polaires ont beaucoup gagné en popularité, au point où une équipe de chercheurs s'est récemment penchée sur cette forme de tourisme. À l'aide d'un modèle qui servait, à l'origine, à comprendre la nature de la culture, de l'action et des connaissances du développement de la géographie humaine, on a exploré la nature, l'échelle et l'étendue des recherches effectuées en rapport avec le tourisme dans l'Arctique et dans l'Antarctique. Grâce à une démarche comparative, on a mis en évidence les enjeux touristiques qui se ressemblent beaucoup dans les deux régions polaires. La recherche sur le tourisme polaire semble se concentrer sur quatre grands aspects, soit les tendances en matière de tourisme, les incidences du tourisme, les politiques et la gestion du tourisme ainsi que le développement du tourisme. Grâce à l'évaluation de ces aspects de la recherche, on réussit à déterminer les écarts de recherche ainsi que les champs d'enquête qui pourraient éventuellement porter fruits.

Mots clés: tourisme, touristes, recherche sur le tourisme polaire, Arctique, Antarctique, recherche en sciences sociales

Traduit pour la revue Arctic par Nicole Giguère.

\section{INTRODUCTION}

Recent years have seen considerable increases in tourism activity in both northern and southern polar regions. It appears that geographic isolation and a challenging climate, which once precluded tourist visits, are now the very factors attracting them. For various reasons, however, the polar regions are generally regarded as fragile environments, susceptible to change through human activity, and thus present substantial management challenges (Hall and Johnston, 1995). Despite these challenges, some believe there is "increasing recognition that responsible tourism is an appropriate and legitimate activity" in the polar regions (Splettstoesser, 2000:54). Given that tourism is regarded as a legitimate activity - and indeed, a desired industry in some communities-it is urgent that we begin to understand the complexity of polar tourism.

As polar tourism emerges as a major enterprise, it is important to develop a research plan that balances the needs of the environment, indigenous peoples, communities, and the tourists themselves. This is a timely exercise, as the planned International Polar Year (IPY) 2007-08 provides an opportunity to move tourism research higher up the polar social science agenda. Mason and Legg (1999) began this process by highlighting research possibilities for the Antarctic, but we believe our article is the first to suggest lines of inquiry spanning both polar regions. We draw on a model initially developed by Grano (1981) to examine external influences and internal changes in the discipline of geography. Hall and Page (2002) adapted this model as a framework to assess the nature and status of the geography of tourism. Here, we apply the model at a "micro-level" to examine specifically the nature, scale, and scope of tourism research in the polar regions. The model provides a valuable organizational framework within which to situate the particular context of polar tourism research, addressing three interrelated areas: (1) knowledge - the available information and content of the study of polar tourism; (2) action - polar tourism research in the context of research praxis; and (3) culture - academics, students, and other researchers within the context of influences on the research community (e.g., funding bodies, ethics review, community control, and the wider society).

Our definition of the Antarctic, delimited by its ocean boundaries, is self-explanatory (Fig. 1); the definition of the Arctic, however, is much more problematic (Fig. 2). As Nuttall and Callaghan (2000) point out, confusion arises because terms such as "the Arctic," "circumpolar north,"

\footnotetext{
${ }^{1}$ Department of Geography, University of Calgary, 2500 University Drive NW, Calgary, Alberta T2N 1N4, Canada

${ }^{2}$ Corresponding author: ejstewar@ucalgary.ca

${ }^{3}$ School of Outdoor Recreation, Parks and Tourism, Lakehead University, Thunder Bay, Ontario P7B 5E1, Canada

(C) The Arctic Institute of North America
} 


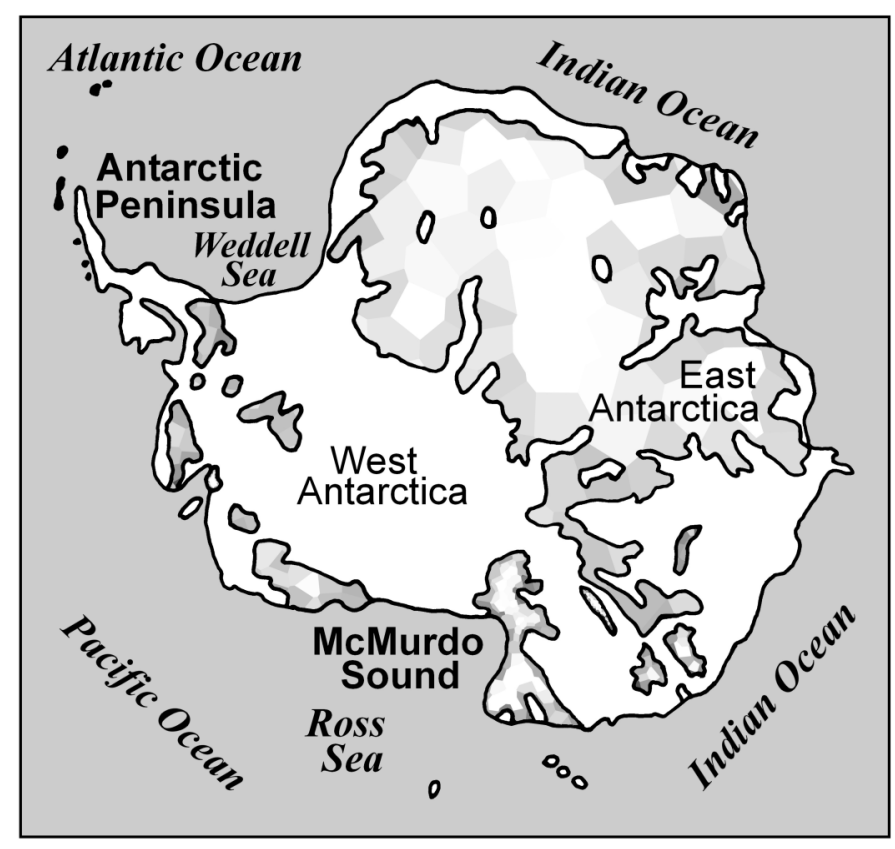

FIG. 1. Map of Antarctica, showing the location of two main visitor destinations: Antarctic Peninsula and McMurdo Sound.

"northern regions," and "the North" have been used interchangeably, depending on the needs of the research discipline. Here we consider the Arctic, as an area of study, to comprise Alaska, northern Canada (Labrador, northern Quebec, northern Manitoba, Nunavut, Northwest Territories, and Yukon Territory), Greenland, Iceland, northern Fennoscandia (Norway, Sweden, and Finland), and northern Russia. Despite the obvious differences between the Arctic and the Antarctic (in terms of sovereignty, use of scientific bases, management regimes, indigenous peoples, legislative control, access, cultural heritage, and physical geography), we use a comparative approach because, with regard to tourism, the major issues are largely similar: regulation of tourism, protection of heritage, management of trans-national space, and impact on local populations (Hall and Johnston, 1995).

\section{KNOWLEDGE}

Several key texts published in the mid 1990s acknowledged the growing interest in polar tourism issues. Among the first publications to focus on Antarctic tourism was a special issue of the Annals of Tourism Research (Smith, 1994a), which brought together for the first time papers by social scientists, biologists, and government planners, with an emphasis on how such expertise could address the multi-faceted challenge of balancing the needs of the environment, science, and tourism (Smith, 1994b). Hall and Johnston's Polar Tourism: Tourism in the Arctic and Antarctic Regions (1995) provided the first comprehensive overview across both polar regions of issues such as patterns of tourism, access, impact on aboriginal peoples,

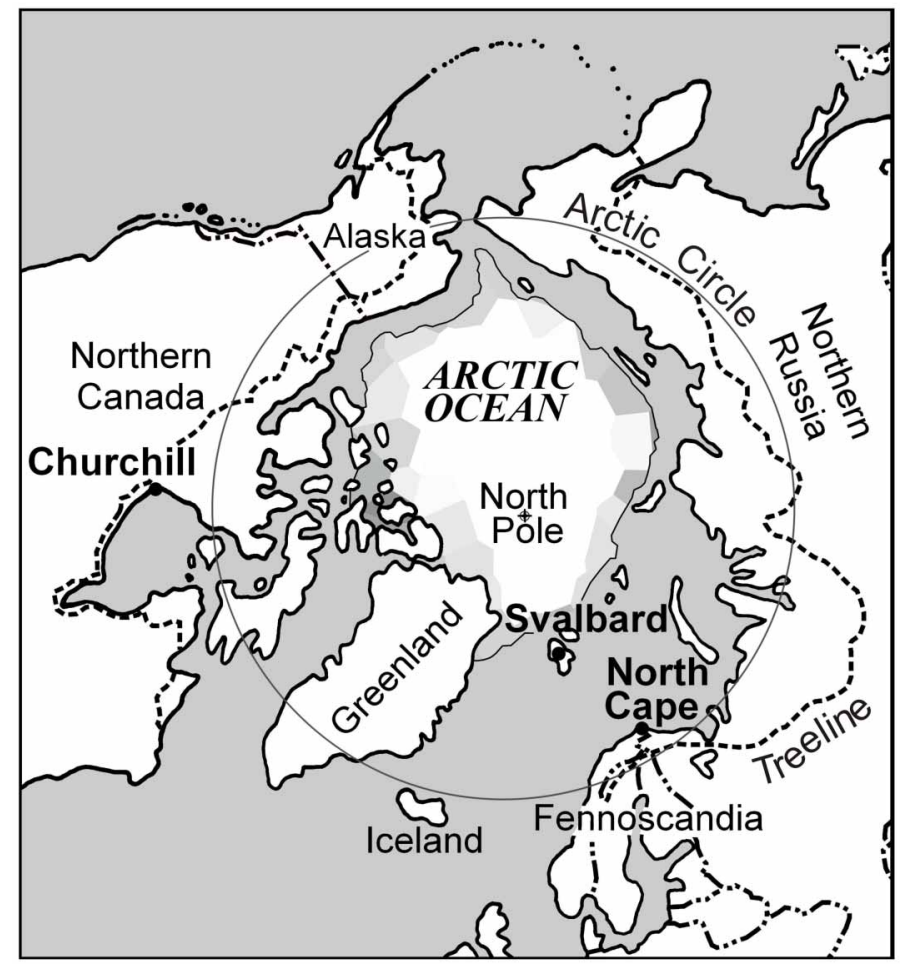

FIG. 2. Map of the Arctic, showing the location of three main visitor destinations: Churchill, Svalbard, and North Cape.

monitoring of tourism impacts, regulation of tourism, and the search for sustainable management regimes. By carefully bringing together the "knowledge base" within one text, this volume clearly established polar tourism as a legitimate research activity with at least some definitions, boundaries, and a corpus of key issues to investigate. The authors hoped that the volume would "provide a basis on which some of the critical policy and management decisions will be based" (Hall and Johnston, 1995:311). Another useful addition to the growing polar tourism literature was Bauer's (2001) Tourism in the Antarctic: Opportunities, Constraints and Future Prospects. Bauer's contribution is particularly noteworthy, as it draws on his experiences and observations of cruises to the Antarctic Peninsula, the Subantarctic Islands, and the Ross Sea, as well as overflights of the continent. Other important contributions to the polar tourism literature include Johnston and Haider (1993), Kempf and Girard (1994), and Humphreys et al. (1998).

Many of these contributions search for a definition of polar tourism. Hall (1992:4) defined tourism as "all existing human activities other than those directly involved in scientific research and the normal operation of government bases." Tourists, defined as "visitors who are not affiliated in an official capacity with an established National Antarctic Programme" (Enzenbacher, 1992:17), include fare-paying passengers, private expeditions, and adventurers aboard sea or airborne vessels. Off-duty research and base personnel, tour operator staff, media, and distinguished visitors are considered to fall outside this 
definition, although it is recognized that they may engage in some tourism activities during their time on the continent. Definitions of Arctic tourism are more characteristic of tourism definitions used elsewhere in the world (Hall and Johnston, 1995). For example, tourism "may be thought of as the relationships and phenomena arising out of the journeys and temporary stays of people travelling primarily for leisure and recreational purposes" (Pearce, 1989:1). An all-encompassing definition of polar tourism is "all travel for pleasure and adventure within polar regions, exclusive of travel for primarily government, commercial, subsistence, military or scientific purposes" (Hall and Johnston, 1995:8). A contentious area within these definitions is how to account for the flight-seeing passengers who travel to view the Antarctic from the air, but do not physically arrive there.

\section{ACTION}

Tourism research has often struggled to defend itself as a legitimate area of scholarly inquiry. However, as Hall (1994:7) argues, "the debate which marks such concepts should be seen as a sign of health and youthful vigour in an emerging area of serious academic study and should be welcomed rather than be regarded as a source of embarrassment." Dann et al. (1988:4) stated that tourism research tends to fall into a number of categories: "theoretical discourse without empirical foundation; descriptive essays which assemble a collection of impressionistic and anecdotal material; and data analysis devoid of theoretical context." Our review of Antarctic and Arctic databases, abstracts, and bibliographical searches indicates that four research clusters are beginning to emerge: tourism patterns, tourism impacts, tourism policy and management, and tourism development.

The clusters described in this article reflect a bias toward North American and European literature and that which is available in the English language through the traditional means of research communication. While we acknowledge only a limited range of studies published through Franco-Canadian or Scandinavian universities and research institutes, we are conscious that these are growing bodies of work (see Granberg, 1998; Grenier, 2003, 2004). Similarly, while we refer to some technical and consultancy reports, we are aware that a substantive collection of work on this topic is being published in other, non-academic formats. These omissions from our review are clearly limitations of the literature survey and in essence identify the research culture within which the authors work.

\section{Tourism Patterns}

A particularly strong component of tourism research is the focus on patterns of tourism demand and behaviour. These patterns include aspects such as the motivation, demographics, and numbers of tourists; their routes, destinations, and activities pursued; sources of information; and attitudes, knowledge, skills, and composition of the travelling group. Until the early 1990s, the total number of tourists who had visited Antarctica was difficult to determine with certainty because reporting procedures were not uniform (Enzenbacher, 1992), although some organizations made reasonable estimates (see New Zealand Antarctic Programme, 1991; Beltramino, 1993). In 1991, however, seven tour operators active in Antarctica created a single organization, known as the International Association of Antarctica Tour Operators (IAATO), to advocate, promote, and practise environmentally responsible private-sector travel to Antarctica (Splettstoesser, 2000). Since 1992, there has been reliable recording of individuals, groups, and companies travelling to Antarctica. Member companies are required to provide information annually on all their activities within Antarctica. Additionally, IAATO has secured as much information as possible on tour operators who are not IAATO members and their plans for current seasons (IAATO, 2005).

Antarctica is likely to remain a specialized and relatively expensive niche destination offered by a limited number of experienced operators who focus on educational voyages to areas of natural and historic value. Key tourist areas are the Antarctic Peninsula and Ross Island in McMurdo Sound (Fig. 1). Some 6000-14000 visitors travelled to Antarctica each season through the 1990s, and tourism peaked in the millennium summer 1999-2000 (13826 visitors). From November 2002 to March 2003, 13571 tourists landed in the Antarctic, a 16\% increase from the 2001-02 season. They arrived on 26 commercially organized tour vessels (some of which made up to ten repeat visits during the season) as well as numerous sailing vessels and yachts (IAATO, 2005). Although seaborne tourism (with landings) decreased during 2000-03 from the millennium peak, this peak was exceeded in the 2003-04 season, when 19772 visitors landed on the continent. IAATO estimated that 21216 visitors would land in Antarctica during the 2004-05 season (see the IAATO website for more detailed statistics on tourist numbers in Antarctica). Some baseline data on specific site visits are beginning to be compiled through projects such as the USAbased "Oceanites" Antarctic Peninsula site inventory project (Naveen, 1999; Kriwoken and Rootes, 2000). This work is helpful for determining visitor numbers at particular sites, although it does not extend into recording the tourists' movements and activities.

The Arctic and Subarctic attract a far greater number of tourists than their southern counterparts, as they have a much longer tourism tradition, better accessibility, and a wider diversification of destinations and attractions than Antarctica (Hall and Johnston, 1995). It is almost impossible to estimate the number of visitors to the Arctic: there are eight countries with Arctic or Subarctic territory, or both, which makes it difficult to collect comparable data. Tourists do not necessarily physically leave one continent 
and arrive at another (as they must do to reach Antarctica), and since many destinations are without border crossings, it is difficult to determine whether travel is tourismrelated. Finally, although it is relatively easy to track passenger numbers on board large cruise ships, it is problematic to track numbers of visitors on independent cruises (Hall and Johnston, 1995). Tourism in the Arctic uses modes of transport that are not feasible in Antarctica, such as a regular passenger air transport and a road network (Lundgren, 1999). Finally, the Arctic has no body equivalent to the IAATO, certainly not one that spans the national boundaries, although the creation of such a body has been suggested (Splettstoesser, 2000).

In many cases, statistics exist for specific places and regions in the Arctic (Hall and Johnston, 1995). One of the best-known Canadian polar destinations is the town of Churchill, Manitoba, internationally renowned for its wildlife viewing opportunities (Newton et al., 2002). Lemelin (2005) reports that between 4000 and 6000 tourists visit Churchill annually to view polar bears (Fig. 2). The Canadian Tourism Commission collects a range of tourism statistics. A series of reports in the mid 1990s reviewed domestic and inbound markets for tourism to Canada's North and the opportunities and challenges these markets presented (GNWT, 1990; Rodgers, 1996a, b). The provinces and territories within Canada also collect statistics on tourism; for example, the Department of Resources, Wildlife and Economic Development in the Northwest Territories estimates that approximately 33000 non-resident leisure travellers visited the Northwest Territories in 1999-2000. Major areas of interest were road touring, outdoor adventure, hunting, fishing, and aurora borealis viewing (GNWT, 1990, 2003). These Northwest Territories figures alone exceed even the most generous estimates of visitors to Antarctica.

Attempts have also been made to assimilate data on tourism in the European Arctic, defined as the northern mainland part of Scandinavia, Svalbard, Greenland, Iceland, and northern Russia (Jacobsen, 1994). Each year the islands of Svalbard (Fig. 2) attract an estimated 2000 tourists, and an additional 15000-20000 visit by cruise ship (Loland, 2005). The long tradition of tourism in Norway started as early as 1845 , with regular steamship tours conducted from Norway's most northerly town, Hammerfest, to North Cape (Fig. 2). Today, North Cape draws thousands of visitors (Visit Norway, 2004). The early steamship tours established the beginnings of tourism in the Arctic over 100 years before its first appearance in Antarctica. Antarctic tourism is generally considered to have begun in the 1950s, when more than 500 fare-paying passengers travelled from Chile and Argentina to the South Shetland Islands (Headland, 1994).

\section{Tourism Impacts}

Polar regions symbolize the world's last great wildernesses, so it is not surprising that much research has focused on the effects of tourism activity, particularly the increasing numbers of tourists, on what is perceived as the fragile polar environment. According to many researchers, environmental impact is the most prominent issue surrounding tourism in Antarctica, although the impact of tourism may be insignificant compared to the damage created by the construction of Antarctic bases, the refuse they generate, and the harvesting of marine life, or to the potential effects of oil and mineral exploration and extraction (Hall, 1992). Some have suggested that an increase in visitors is likely to lead to greater impact on the environment and wildlife, particularly because tourist sites are generally located on the coast. Coastal areas are more vulnerable because they are free of permanent ice cover, and these are the sites used by wildlife for daily and seasonal activities. Antarctic tourist activity is concentrated in the austral summer (November to February), during the period of ice thaw, which corresponds to the breeding seasons of a number of indigenous species (Mason and Legg, 1999), and this timing adds significantly to the likelihood of environmental damage (Hall and Wouters, 1995). This situation might be exacerbated on the Subantarctic Islands, where the specialization of the island biota makes them highly susceptible to disturbance, particularly to human-induced effects (Hall, 1993; Cessford and Dingwall, 1994).

Little empirical evidence exists, however, to indicate conclusively that tourists have a significant negative effect on the ecology of Antarctica. "Whether visits to wildlife colonies impose anything more than a minor or transitory impact, either by tourists or scientists, has yet to be quantified" (Splettstoesser, 2000:52). Indeed, Headland (1994) estimated that on the basis of "presence-days" less than $1 \%$ of human impacts can be attributed to tourists; scientists and government personnel account for almost all the impact. Today, given the large increases in tourist numbers, a re-calculation of this percentage is needed. The "precautionary principle" could be applied in the management of polar tourism. Put simply, the principle suggests that scientific uncertainty should not be a reason to delay implementation of measures to prevent environmental damage, "so long as the weight of evidence suggests action is appropriate" (Draper and Reed, 2005:24).

Several studies do warn us that there might be a link between human presence and disturbance to Antarctic wildlife. Recent biological research into diseases of Antarctic wildlife has tentatively identified a wide range of potential disease-causing organisms in Antarctic fauna. A primary concern is that humans might transmit important pathogens between wildlife colonies (Curry et al., 2001). When visiting wildlife sites, tourists walk between groups of animals and inevitably collect excreta on their boots. Tour operators use decontamination guidelines developed by IAATO, which require visitors to rinse their boots in seawater on leaving the site. On re-boarding the ship, they scrub any remaining material off their boots and rinse them again. The boots are then allowed to dry out in the 
ship before the next landing. Curry et al. (2001) conclude, however, that the current boot-cleaning procedure may not be adequate to prevent transmission of bacterial pathogens by tourists visiting Antarctic wildlife colonies.

A growing body of research is examining the effects of aircraft operations near concentrations of Antarctic birds such as Adélie, Gentoo, Emperor, and King penguins (see Harris, 2001 for an excellent overview). For example, Nimon and Stonehouse (1995) and Nimon (1997) investigated Gentoo penguin responses to tourists and other disturbances (such as overflights) in Antarctica. However, Harris (2001) states that so far work is inconclusive, and much research is needed to establish reliable guidelines.

The assessment of environmental effects of tourists and their activities in the polar regions is in its infancy, although there are some promising initiatives. The most significant of these is the UK-based Scott Polar Research Institute "Project Antarctic Conservation" (1990-2000), which aimed to study the development, evolution, and environmental impacts of tourism (Stonehouse and Crosbie, 1995; Crosbie, 1999). Despite these efforts, many nations have not widely supported research directed at tourism impacts (Kriwoken and Rootes, 2000). Clearly, this is of great concern because if tourism activities are not addressed adequately, "the impacts may not be appropriately considered and could pose unacceptable risks to an environment supposedly legally safeguarded by international treaty" (Hemmings and Roura, 2003:13). We note, however, that the Australian Antarctic Division and Antarctica New Zealand have recently embraced the "Antarctic tourism debate" (see Antarctica New Zealand, 2000; Australian Antarctic Division, 2004) and have also supported researchers investigating tourism impact issues (see Maher, 2002; Maher et al., 2003).

Although the impacts of tourism on the Antarctic continent are seen predominantly as environmental, substantial concerns also exist about the impacts of tourism on Antarctica's cultural heritage (Hall, 1992; Steel and Kirby, 1997; Kirby et al., 2001; Antarctic Heritage Trust (New Zealand), 2005). Much of the cultural heritage of the region is of interest to tour operators. Historic huts and other sites are powerful symbols of past human endeavour and, as such, are highly attractive destinations to potential clients. A number of early sealing and whaling sites exist on the Antarctic Peninsula and Subantarctic Islands, and several early explorer sites are found in the Ross Dependency and in the Australian sector (Antarctic Heritage Trust (New Zealand), 2005). Even though the number of visitors to historic sites has increased, in line with general trends in Antarctic tourism, the concept of "carrying capacity" is not well known or applied. In the Ross Dependency, however, the Antarctic Heritage Trust (New Zealand) has set specific carrying capacities for all of the huts under its care (Hughes and Davis, 1995; Antarctic Heritage Trust (New Zealand), 2005). There is also concern regarding "souveniring," a polite term for the theft of artefacts from the historic sites (Hughes and Davis, 1995), although it is thought that "in the past this was more a result of the activities of scientists, support staff and expeditioners, rather than tourists" (Mason and Legg, 1999:78). A more significant issue, however, is how to ensure that such historic resources are sustained for future visitors if this is desired as part of a formal visitor management strategy (Mason and Legg, 1999). Indeed, full conservation of all sites likely is physically and financially impossible.

Economic impacts of tourism in Antarctica have not attracted much research interest. An exception is the work on the Antarctic economy by White (1994:245) who claims that "in the 1990s, for the first time the number of tourists is exceeding the number of scientists and support staff, which makes tourism the most important part of the Antarctic economy when viewed in terms of the number of people, although in dollar terms, the level of science and support expenditures is much greater." Although not Antarctic tourism destinations themselves, cities such as Christchurch, New Zealand, and Hobart, Australia, which act as staging posts for travel to and from Antarctica, might reap substantial economic benefits from Antarctic tourism. In the Arctic, by contrast, the economic potential of tourism has long been the subject of discussion (Adderly, 1990). According to Hinch and Swinnerton (1993), economic development is the driving force behind tourism in the North. Two issues that have been identified are the problem of distributing economic benefits and the focus on short-term gains at the expense of more sustainable economic development. But it appears that little is really known about the actual economic contribution of tourism in the Arctic, taking into account "leakages" and cumulative implications of growth (Hinch and Swinnerton, 1993). This is somewhat surprising, as in other tourism areas we often know most about economic effects, which are more easily measured than other forms of impact.

Clearly socio-cultural impacts of tourism have been explored to a greater degree in the Arctic than in Antarctica. In a useful review of trends in indigenous tourism development in Canada's western Arctic region, Notzke (1999) highlighted the importance of educating tourists about their role in aboriginal people's lives. Anthropological studies of socio-cultural impacts have articulated the stress that tourism has placed on aboriginal peoples (Smith, 1989; Wolfe-Keddie, 1993). Aboriginal land claims, native self-government, the devolution of power from the federal to the territorial governments, and experience with other resource-development issues have produced a more sophisticated resident. Though many local community groups have endorsed tourism wholeheartedly, a significant number remain sceptical or disinterested. This absence of an initial euphoria may indicate a cautious approach toward tourism. The attitude of indigenous and non-indigenous people in northern Canada toward the tourism industry remains to be determined (Hinch and Swinnerton, 1993).

A study of Inuit perceptions of tourism development in Clyde River (Baffin Island, now in Nunavut) revealed 
indigenous support for the growth of tourism as long as its development was gradual and the community maintained control of the industry (Nickels et al., 1991). However, another study in this area reported that aboriginal people were not playing a leading role within the tourism industry (Hinch, 1993). Several graduate research projects also address this issue. For example, a stakeholder analysis of nature-based tourism in the Beaufort Sea-Mackenzie Delta Region (Northwest Territories) revealed that community stakeholders, and in particular, Inuvialuit elders and tour operators, thought that the economic potential of naturebased tourism was high and, consequently, support for it was also high (Dressler, 1999). An ethnographic study of Japanese tourists conducted in Yellowknife, Northwest Territories, revealed general support by their hosts (Carpenter, 2000). Similarly, a study of community-level effects of tourism at Pond Inlet (now in Nunavut) suggested that residents generally supported tourism (Grekin, 1994). A study of resident perceptions of tourism development at Baker Lake (now in Nunavut) determined that tourism is at its preliminary stage of development, and in confirmation of results obtained elsewhere, noted that attitudes toward tourism are generally positive (Woodley, 1994). Elsewhere in the Arctic, Viken (1998) examined the roles that Saami people have taken in tourism and observed that in many ways, the Saami culture intersects positively with the tourism industry.

\section{Tourism Policy and Management Issues}

A third important research cluster examines polar tourism issues in light of key policy issues and legislation (Humpreys et al., 1998; Bauer and Dowling, 2003). For example, the effects of tourism on the Antarctic continent are often considered in the context of the 1991 Madrid Protocol, which codified and made legally binding a number of environmental protection measures (Hansom and Gordon, 1998). Annex One of the Protocol legally requires all tour companies registered in Treaty signatory states to conduct environmental impact assessments (EIAs) for their Antarctic operations, whether shipborne, landborne, or airborne, including overflights (Kriwoken and Rootes, 2000). Authors who have tried to evaluate the evolving institutional arrangements for EIA in Antarctic tourism have concluded that the tourism industry and Treaty signatory nations need to work more closely together if the EIA charter of the Madrid Protocol is to be fulfilled (Kriwoken and Rootes, 2000). An important observation is that the difficulty of applying to commercial tourism an EIA system designed primarily to assess national programme activities "is not an argument for absolving tourist activities" from the obligations of the Madrid Protocol (Hemmings and Roura, 2003:13).

The development of visitor codes of practice and assessments of their effectiveness has also aroused keen debate (Johnston, 1997, 1998; Mason, 1997; Splettstoesser, 2000). In response to the concern that tourists adversely affect the places they visit, IAATO developed a code of conduct for tourists that attempts to minimize their effects on the environment. Visitors on board IAATO member expeditions are reminded, for example, to stay with the group when ashore and to leave nothing behind, and cautioned not to disturb wildlife, walk on fragile plants, interfere with protected areas or scientific research, enter historic huts unless escorted by an authorized person, or smoke during shore excursions (Bauer and Dowling, 2003). However, apart from the work of Davis $(1995,1999)$, little is known about actual visitor behaviour once on shore and whether or how strictly such guidelines are adhered to. Additional IAATO guidelines require tour operators to be familiar with the Antarctic Conservation Act 1978 and to abide by it, to be aware of protected areas, to enforce the visitor code of conduct, to hire a professional team of expedition leaders, to provide a qualified lecturer/naturalist guide for every $20-25$ passengers to supervise small groups ashore, and to limit the number ashore at any one place and time to 100 passengers (Bauer and Dowling, 2003).

Despite these environmental concerns, there are claims, difficult to prove and so far unsubstantiated, that Antarctic tourists are the best possible ambassadors for the Antarctic, as they spread the message about the need for environmental protection when they return home (Splettstoesser, 2000; Maher, 2002; Maher et al., 2003; Roy-Sole, 2005). In the Arctic, growing concerns about the relationship between tourism and the environment have begun to be addressed through the World Wide Fund for Nature's Arctic Tourism Project (1995-2000), which aimed to use tourism to promote conservation and to maximize benefits of tourism to local communities (Humphreys et al., 1998; Mason et al., 1999). Furthermore, a number of communities and governments have implemented restrictions appropriate to their individual circumstances and concerns.

The implementation and effectiveness of such efforts has become an additional focus of research. For example, Johnston (1997), summarizing several approaches to visitor regulation in both the Arctic and the Antarctic, suggested that the approach taken in Antarctica (a combination of codes of conduct and an evolving legislative framework) has much to offer an Arctic-wide strategy (Johnston, 1997). In a later article, Johnston (1998) discussed different ways of evaluating visitor regulation strategies. She concluded that, in addition to criteria-based evaluation, comparative studies are particularly important to illustrate how different strategies work in the Arctic and the Antarctic. Davis (1995) asks whether guidelines themselves are enough to limit the impacts of tourists in the Antarctic and, along with other authors, goes on to consider the Recreation Opportunity Spectrum (ROS) and Limits to Acceptable Change (LAC) models as possible approaches to the challenges of Antarctic tourism (Davis, 1995, 1999; Tracey, 2000). Along these lines, the approach to nature management in Svalbard, commonly touted in Norway as the bestmanaged wilderness in the world, offers insights for other 
northern regions attempting to manage tourism (Kaltenborn, 2000). Tracey (2000) takes a comparative approach in his comprehensive examination of Antarctic tourism patterns, values, management issues, regulations, and developments. He describes the relative weaknesses of the tourism management system in the Antarctic in comparison to other locations and when assessed within management planning theory. He proposes an alternative management approach that would work within the Antarctic Treaty system and would be responsive to current patterns and predicted developments.

\section{Tourism Development}

The three research clusters examined so far relate to both polar regions, but the final cluster that has been identified-issues relating to tourism development-is represented almost entirely by research in the Arctic. This is not surprising, as the Arctic has a longer history of tourism than the Antarctic and is home to indigenous peoples, conditions that present many interesting and challenging development questions.

A major theme in this research cluster is the need to work toward development that is sustainable in the broadest sense (environmentally, socio-culturally, and economically) and to implement strategies that ensure sustainability is a central component of tourism development. Numerous case studies on sustainability have been published. Canadian examples include the need to foster community economic and social well-being in the development of a new national park on Banks Island in the Northwest Territories (Wright and McVetty, 2000); the tensions between conservation, tourism, and development in the northern Yukon (Marsh and Johnston, 1983); community tourism development across the Northwest Territories (Marshall Macklin Monaghan Ltd., 1982); and the challenge on Ellesmere Island of balancing preservation and access requirements for national parks (England, 1982). Outside the Canadian Arctic, a management plan for tourism and outdoor recreation in Svalbard aimed to safeguard the environment while keeping tourism development within environmentally sustainable and commercially acceptable boundaries (Kaltenborn, 2000), while tourism development assets in Greenland were examined as both opportunities and challenges (Timothy and Olsen, 2001).

\section{CULTURE}

Development of these four research clusters is an encouraging sign that research on tourism in polar regions is starting to be viewed as a legitimate area of investigation. Research into polar tourism issues tends to be characterized by empirical work that attempts to describe systematically and along themes, sometimes through case studies, and by description without explanation that is geared toward practical issues and management. The shortfall has been in an overall lack of empirical research and in applying existing tourism theory to the polar regions. This is not a criticism; this situation is symptomatic of the nature of any new and emerging research "project."

Nevertheless, much work is needed if we are to improve our understanding of how tourism in the polar regions relates to societal need and how the regions can be better protected, and to do this work, we must address a number of "cultural" research issues. In some instances, there appears to be an unwillingness-possibly due to unfocused research in the past - to subject paying guests to scrutiny (although, dare we say it, some guests might actually enjoy this debate). Some commercially sensitive tour operators are reluctant to pose certain types of questions in visitor surveys (Bauer, 2001) and express doubts about the uses to which this information is or may be put. Many logistical and environmental issues also make this type of research extremely hard to administer, for example, problems in gaining access to remote communities, lack of local community interest in research, and limited funding for tourism research from national agencies because it generally falls outside the traditional natural sciences domain of polar research. Thus, the field is characterized by a scattered research community, and it must contend with a general belief that further research is not warranted. These concerns are mirrored somewhat in the wider field of tourism studies, in that tourism is not regarded as a serious scholarly subject and that the theorization of tourism research, in general, is relatively weak. It is also early days in polar tourism, and the nature of the research may reflect this, particularly in the lack of theoretical foundations. Clearly some of these issues are relevant to polar research generally and some are specific to tourism research.

\section{DISCUSSION}

Despite emerging research clusters, we really know very little about the phenomenon of tourism in polar regions. Tourist numbers are low in relation to international tourism numbers in general (Jacobsen, 1994), but the number of visitors should not necessarily determine the quantity (and quality) of research. The polar regionsthe last great terrestrial wilderness-have come to symbolize remoteness, extreme conditions and environmental vulnerability, so it would seem responsible and important to move empirical research forward in a coordinated and focused manner. As polar tourism gains momentum, it is time to develop a research plan that not only protects the environment but also is connected to societal needs and prioritized according to expected benefits (Harman, 2003). We need high-impact scholarship, that is, research that satisfies our deep curiosity, solves practical problems, and contributes to public policy. This means that, in the Arctic particularly, local and regional interests must be basic components of tourism research. Local communities as well as national ones will need to have a say in how 
TABLE 1. Development of existing research clusters and new research clusters (Part A after Mason and Legg, 1999).

\begin{tabular}{|c|c|c|c|}
\hline \multicolumn{4}{|c|}{ Part A: Existing Research Clusters } \\
\hline & $\begin{array}{l}\text { Generic Polar Tourism } \\
\text { Research Needs }^{1}\end{array}$ & $\begin{array}{l}\text { Specific Antarctic and Subantarctic } \\
\text { Research Needs }\end{array}$ & $\begin{array}{l}\text { Specific Arctic and Subarctic } \\
\text { Research Needs }\end{array}$ \\
\hline Tourism Patterns & $\begin{array}{l}\text { - on-site behaviour } \\
\text { - motivations and attitudes } \\
\text { - latent demands and constraints }\end{array}$ & $\begin{array}{l}\text { - baseline measures of independent tourists } \\
\text { - tourist demographics }\end{array}$ & $\begin{array}{l}\text { - comprehensive circumpolar tourist } \\
\text { statistics } \\
\text { - destination decision-making }\end{array}$ \\
\hline Tourism Impacts & $\begin{array}{l}\text { - baseline measures of tourism effects } \\
\text { on the environment }\end{array}$ & $\begin{array}{l}\text { - polar and non-polar community responses } \\
\text { to tourism } \\
\text { - economic impacts of tourism in 'hub' cities } \\
\text { - within-and between-user group conflict }\end{array}$ & $\begin{array}{l}\text { - longitudinal analysis of the economic, } \\
\text { social, and environmental effects on host } \\
\text { communities } \\
\text { - effects of tourism on communities and } \\
\text { culture }\end{array}$ \\
\hline $\begin{array}{l}\text { Tourism Policy \& } \\
\text { Management Issues }\end{array}$ & $\begin{array}{l}\text { - effectiveness of tourism regulation } \\
\text { and governannce } \\
\text { relationship between science and } \\
\text { tourism }\end{array}$ & - operators as managers & $\begin{array}{l}\text { - effectiveness of circumpolar tourism } \\
\text { regulation and governance } \\
\text { relationship between Arctic science, } \\
\text { tourism, and community } \\
\text { - partnerships and networks }\end{array}$ \\
\hline Tourism Development & $\begin{array}{l}\text { - relationship between tourism } \\
\text { development and sustainability } \\
\text { - tourism supply issues }\end{array}$ & $\begin{array}{l}\text { - access to key cultural and natural sites } \\
\text { of interest }\end{array}$ & $\begin{array}{l}\text { - community involvement in and } \\
\text { responses to tourism } \\
\text { - endogenous and exogenous influences } \\
\text { on development }\end{array}$ \\
\hline
\end{tabular}

Part B: New Research Clusters

\begin{tabular}{|c|c|}
\hline & Generic Polar Tourism Research Needs ${ }^{1}$ \\
\hline Tourist Experience & $\begin{array}{l}\text { - nature and quality of the tourist experience } \\
\text { - expectations, knowledge, experience, and satisfaction } \\
\text { - tourist's post-visit behaviour with regard to ambassadorial activities } \\
\text { - effects of travel on tourist }\end{array}$ \\
\hline $\begin{array}{l}\text { Global Changes and } \\
\text { Large-Scale Influences }\end{array}$ & $\begin{array}{l}\text { - global climate change adaptations and implications for tourism } \\
\text { - large-scale influences on tourism (e.g., terrorism, economic, social, environmental) }\end{array}$ \\
\hline
\end{tabular}

${ }^{1}$ Applicable to both polar regions.

priorities are developed. Indeed, partnership in research is an absolute necessity in the North (Watt-Cloutier, 2000).

In Table 1, following Mason and Legg (1999), we outline how the existing research clusters identified in this article can be developed and extended in both generic and specific senses. Table 1 also highlights other potential lines of inquiry by proposing new generic research clusters that apply to both polar regions. Since the research clusters reflect the similarity of major tourism issues across the polar regions, there is considerable duplication in the suggested lines of inquiry.

It is critical to establish a clear picture of polar tourism patterns: without the collection of reliable and comparable baseline data, it is difficult to imagine how policy and decision makers will be prepared as tourism becomes embedded in these regions. Currently, the knowledge base available is quite variable across both polar regions, with extensive detail on certain elements and sparse data on others. In general, on-site behaviour of polar tourists, their motivations and attitudes, and latent demand and constraints are important areas to investigate. More specifically for the Antarctic, we suggest extending the valuable data-collection functions of IAATO to include visitor socio-demographics and research on independent "adventure" tourists. To achieve comparable information on tourist activities in the Arctic is challenging, not least because the Arctic spans eight countries; nevertheless, this task is critical to quantifying the scale and scope of pan-Arctic tourism.

Although largely in its infancy, the study of tourism impacts is emerging as a strong research theme. As Jones (1998) suggests, it is important to use conceptually based work to deepen our understanding of not only the growth in visitor numbers, but its likely effects. We suggest building on the good work already done to establish baseline data on effects of visitation to sites of both natural and cultural interest. More specifically for the Arctic, we suggest longitudinal analysis of tourism's socio-cultural and economic effects, particularly in coastal communities that are likely to see increases in cruise tourism as sea ice conditions change. Findings from such research will have important implications for policy makers, communities, and the polar travel industry.

Additional general lines of inquiry are emerging from current work on polar tourism policy and management issues. 
These include the effectiveness of the evolving framework of tourism regulation and governance (and the lessons that can be applied from Antarctica to the Arctic) and the relationship between science and tourism activities. The latter is of particular interest in Antarctica, where tourism is likely to become the dominant human activity (Mason and Legg, 1999). For the Arctic we suggest that the relationship between science, communities, and tourism be further scrutinized in light of the IPY and the inevitable increases in polar science (and possibly tourism) activities.

The underlying theme of research on tourism in the polar regions is broadly concerned with tourism development that is environmentally, socio-culturally, and economically sustainable. If tourism in the Arctic aspires to be sustainable, decision makers need to understand and integrate local knowledge into the planning process. "In this way," as Murphy (1985:176) states, "existing or new destinations may create more community control over the pace and style of their tourism development." The challenge for community-level planning is to find ways to direct powerful sets of outside interests (such as the tourism industry and the government) and to work not only with the local interests that benefit economically from tourism, but also with those that suffer from its impacts (Wolfe-Keddie, 1993). To augment our understanding, participatory research methodologies (such as participatory action research and participatory geographic information systems) should be used to examine community involvement in and responses to tourism development.

Our first new research cluster concentrates on tourist experience. As Mason and Legg (1999) indicate, little detailed information is available on the quality of polar tourist experiences. Important areas for general investigation across both polar regions are visitors' expectations, their knowledge base (pre- and post-visit), their site experience, and their overall satisfaction. A particularly interesting line of inquiry, building on emerging work in Antarctica, is the effect of polar travel on the tourists' postvisit ambassadorial activities (Maher et al., 2003).

Our second new research cluster focuses on global changes and large-scale influences on polar tourism. Important areas for investigation are the costs and benefits to polar travel associated with changing global climate patterns, as well as the resulting adaptations required by the travel industry. Predictions of a relatively ice-free Arctic by 2050 raise many questions about cruise tourism in Arctic coastal areas (Marsh and Staple, 1995). Not the least of these concerns is the potential effect of tourism and tourists on remote communities (Jones, 1999). The cruise industry might benefit from climate change, but shorter winters and reduced ice coverage might mean loss of the flora and fauna that attract tourists to the Arctic in the first place. The World Tourism Organization (2003) warns that the circumpolar region is unprepared to tackle these issues and suggests involving all Arctic nations in monitoring the implications of climate change on tourism.

\section{CONCLUSION}

The research areas described previously provide a starting point for addressing the dual challenge of responding to human need and promoting the health of the discipline. If this proposed research plan fails to generate applied outcomes, then the discipline will be, as Harman (2003:418) cautions, "eventually consigned to obscurity." If the polar regions are to retain their status as the earth's last great terrestrial wildernesses, it is vital to develop this research plan in a robust manner so that the findings can be used to inform important decisions that lie ahead in the management of the polar regions. The ongoing preparation for the International Polar Year will be an important catalyst for bringing together diverse groups with interests in polar research, including northern communities, the science community, tourism researchers, granting bodies, nongovernmental organizations, regulatory bodies, and national communities.

\section{ACKNOWLEDGEMENTS}

The authors wish to thank Cathy Chapin, Cartographer at the Department of Geography, Lakehead University, for creating the maps used in this article; Pat Maher at Lincoln University, New Zealand, for useful comments on an early draft; Alain Grenier at the University of Lapland, Finland; and the editor and two anonymous reviewers for their insights and suggestions.

\section{REFERENCES}

ADDERLY, B. 1990. Tourism management in the Northwest Territories. Paper presented at York University Northern Studies Symposium, 15 November 1990, Toronto, Ontario.

ANTARCTIC HERITAGE TRUST (NEW ZEALAND). 2005. www.heritage-antarctica.org/index.cfm/default/. Accessed 30 March 2005.

ANTARCTICA NEW ZEALAND. 2000. Proceedings of the Antarctic Tourism Workshop. Christchurch: Antarctica New Zealand.

AUSTRALIAN ANTARCTIC DIVISION. 2004. Implementation plan for national science priorities. Kingston, Tasmania: Department of the Environment and Heritage, Australian Antarctic Division.

BAUER, T. 2001. Tourism in the Antarctic: Opportunities, constraints and future prospects. London: The Haworth Hospitality Press.

BAUER, T., and DOWLING, R. 2003. Ecotourism policies and issues in Antarctica. In: Fennell, D., and Dowling, R., eds. Ecotourism policy and planning. London: Centre for Agriculture and Biosciences International. 309-329.

BELTRAMINO, J.C.M. 1993. The structure and dynamics of Antarctic population. New York: Vantage Press. 
CARPENTER, B. 2000. Japanese ecotourism in the Northwest Territories, Canada. Master of Science thesis, University of Calgary, Calgary, Alberta, Canada.

CESSFORD, G., and DINGWALL, P. 1994. Tourism on New Zealand's Sub-Antarctic Islands. Annals of Tourism Research 21(2):318-332.

CROSBIE, K. 1999. Monitoring and management of tourist landing sites in the maritime Antarctic. PhD dissertation, Cambridge University, Cambridge, England.

CURRY, C., McCARTHY, J., DARRAGH, H., WAKE, R., TODHUNTER, R., and TERRIS, J. 2001. Could tourists transmit infectious agents in Antarctica? Washington, D.C.: International Association of Antarctica Tour Operators (IAATO).

DANN, G., NASH, D., and PEARCE, P. 1988. Methodology in tourism research. Annals of Tourism Research 15(1):1-28.

DAVIS, B. 1995. Antarctic visitor behaviour: Are guidelines enough? Polar Record 31(178):327-334.

. 1999. Beyond guidelines: A model for Antarctic tourism. Annals of Tourism Research 26(3):516-533.

DRAPER, D., and REED, M.G. 2005. Our environment: A Canadian perspective. 3rd ed. Toronto: Thomson Nelson.

DRESSLER, W.H. 1999. Nature-based tourism and sustainability in the Beaufort-Delta Region, Northwest Territories: An analysis of stakeholder perspectives. Master of Natural Resource Management thesis, University of Manitoba, Manitoba, Canada.

ENGLAND, J. 1982. Tourism on Ellesmere: What's inside the package? Northern Perspectives 10(4):2-7.

ENZENBACHER, D. 1992. Tourists in Antarctica: Numbers and trends. Polar Record 28(164):17-22.

GNWT (GOVERNMENT OF THE NORTHWEST TERRITORIES). 1990. Tourism: The northern lure. Yellowknife: Department of Economic Development and Tourism.

- 2003. Parks and tourism: Tourism research and statistics. Yellowknife: Department of Resources, Wildlife and Economic Development.

GRANBERG, L., ed. 1998. Polar tourism in the Northern sea route/ Northeast passage: The difficulties facing the industry. Helsinki: Aleksanteri Institute.

GRANO, O. 1981. External influence and internal change in the development of geography. In: Stoddart, D.R., ed. Geography, ideology and social concern. New Jersey: Barnes and Noble Books. 17-36.

GREKIN, J. 1994. Understanding the community level impacts of tourism development: The case of Pond Inlet, Northwest Territories. Master of Arts thesis, McGill University, Montreal, Quebec.

GRENIER, A.A. 2003. Croisières et tourisme polaire dans le passage du Nord-Est, Rovaniemi, Finland: Université de Laponie et Éditions Katabatik. . 2004. The nature of nature tourism. Rovaniemi, Finland: University of Lapland Press.

HALL, C.M. 1992. Tourism in Antarctica: Activities, impacts and management. Journal of Travel Research 30:2-9.

- 1993. Ecotourism in the Australian and New Zealand SubAntarctic Islands. Tourism Recreation Research 18(2):13-21. 1994. Tourism and politics: Policy, power and place. London: John Wiley and Sons Ltd.
HALL, C.M., and JOHNSTON, M.E., eds. 1995. Polar tourism: Tourism in the Arctic and Antarctic regions. Chichester: John Wiley and Sons Ltd.

HALL, C.M., and PAGE, S.J. 2002. The geography of tourism and recreation: Environment, place and space. 2nd ed. London: Routledge.

HALL, C.M., and WOUTERS, M. 1995. Issues in Antarctic tourism. In: Hall, C.M., and Johnston, M.E., eds., Polar tourism: Tourism in the Arctic and Antarctic regions. Chichester: John Wiley and Sons Ltd. 147-166.

HANSOM, J.D., and GORDON, J.E. 1998. Antarctic environments and resources: A geographical perspective. Harlow, United Kingdom: Longman.

HARMAN, J.R. 2003. Whither geography? The Professional Geographer 55(4):415-421.

HARRIS, C. 2001. Guidelines for the operation of aircraft near concentrations of birds. Grantchester, United Kingdom: Environmental Research and Assessment.

HEADLAND, R.K. 1994. Historical development of Antarctic tourism. Annals of Tourism Research 21(2):269-280.

HEMMINGS, A.D., and ROURA, R. 2003. Antarctic tourism - A square peg in a round hole: Fitting impact assessment under the Antarctic Environmental Protocol to Antarctic tourism. Impact Assessment and Project Appraisal 21(1):13-24.

HINCH, T.D. 1993. Northern hosts: Aboriginal people and tourism. Northline 13(3):10.

HINCH, T.D., and SWINNERTON, G.S. 1993. Tourism and Canada's North-West Territories: Issues and prospects. Tourism Recreation Research 18(2):23-31.

HUGHES, J., and DAVIS, B. 1995. The management of tourism at historic sites and monuments. In: Hall, C.M., and Johnston, M.E., eds. Polar tourism: Tourism in the Arctic and Antarctic regions. Chichester: John Wiley and Sons Ltd. 235-255.

HUMPHREYS, B., PEDERSEN, A., PROKOSCH, P., SMITH, S., and STONEHOUSE, B. 1998. Linking tourism and conservation in the Arctic. Proceedings from workshops. Meddelelser No. 159. Troms $\varnothing$ : Norsk Polarinstitutt.

INTERNATIONAL ASSOCIATION OF ANTARCTICA TOUR OPERATORS. 2005. www.iaato.org. Accessed 30 March 2005.

JACOBSEN, J.K.S. 1994. Arctic tourism and global tourism research trends. Research Report 37. Thunder Bay, Ontario: Lakehead University Centre for Northern Studies.

JOHNSTON, M.E. 1997. Polar tourism regulation strategies. Polar Record 33(184):13-20.

- 1998. Evaluating the effectiveness of visitor-regulation strategies for polar tourism. Polar Record 34(188):25-30.

JOHNSTON, M.E., and HAIDER, W., eds. 1993. Communities, resources and tourism in the North. Thunder Bay, Ontario: Lakehead University Centre for Northern Studies.

JONES, C.S. 1998. Predictive tourism models: Are they suitable in the polar environment? Polar Record 34(190):197-202.

1999. Arctic ship tourism: An industry in adolescence. The Northern Raven 13(1):28-31.

KALTENBORN, B.P. 2000. Arctic-alpine environments and tourism: Can sustainability be planned? Lessons learnt from Svalbard. Mountain Research and Development 20(1):28-31. 
KEMPF, C., and GIRARD, L. 1994. Le tourisme dans les regions polaires/tourism in polar regions. Proceedings of the Symposium on Tourism in Polar Areas, 21-23 April 1992, Colmar, France.

KIRBY, V.K., STEWART, E.J., and STEEL, G.D. 2001. Thinking about Antarctic heritage: Kaleidoscopes and filters. Landscape Research 26(3):189-202.

KRIWOKEN, L.K., and ROOTES, D. 2000. Tourism on ice: Environmental impact assessment of Antarctic tourism. Impact Assessment and Project Appraisal 18(2):138-150.

LEMELIN, R.H. 2005. Wildlife tourism at the edge of chaos: Complex interactions between humans and polar bears in Churchill, Manitoba. In: Berkes, F., Huebert, R., Fast H., Manseau, M., and Diduck, A., eds. Breaking ice: Renewable resources and ocean management in the Canadian North. Calgary, Alberta: University of Calgary Press. 183-202.

LOLAND, H. 2005. Svalbard: The land of the cold coasts. Norwegian Ministry of Foreign Affairs. www.explorenorth.com/library/ communities/bl-svalbard.htm. Accessed 9 April 2005.

LUNDGREN, J. 1999. Assessing the Canadian North and Arctic for tourists - past and present. Teoros 18(2):44-51.

MAHER, P. 2002. To the ice and back: An examination of Antarctic tourist experience. In: Chon, K., and Ogle, A., eds. Proceedings of the First Asia Pacific forum for graduate students research in tourism. Macao, SAR: The Institute for Tourism Studies. 272-283.

MAHER, P.T., STEEL, G., and McINTOSH, A. 2003. Antarctica: Tourism, wilderness \& 'ambassadorship'? In: Watson, A., and Sproull, J., Compilers. Science and stewardship to protect and sustain wilderness values. Seventh World Wilderness Congress symposium, 2-8 November 2001, Port Elizabeth, South Africa. Proceedings RMRS-P-27 Ogden, Utah: USDA Forest Service, Rocky Mountain Research Station. 204-210.

MARSH, J., and JOHNSTON, M.E. 1983. Conservation, tourism and development in the North: The case of northern Yukon. Paper presented at the 6th Annual Applied Geography Conference, 12-15 October 1983, Toronto, Ontario.

MARSH, J., and STAPLE, S. 1995. Cruise tourism in the Canadian Arctic and its implications. In: Hall, C.M., and Johnston, M.E., eds. Polar tourism: Tourism in the Arctic and Antarctic regions. Chichester: John Wiley and Sons Ltd. 63-72.

MARSHALL MACKLIN MONAGHAN LTD. 1982. Baffin Regional Tourism Planning Project: Community tourism development plan, Grise Fiord, Ausuittu. Yellowknife: Department of Economic Development and Tourism, GNWT.

MASON, P.A. 1997. Tourism codes of conduct in the Arctic and Subarctic region. Journal of Sustainable Tourism 5(2): $151-165$.

MASON, P.A., and LEGG, S.J. 1999. Antarctic tourism: Activities, impacts, management issues and a proposed research agenda. Pacific Tourism Review 3:71-84.

MASON, P.A., JOHNSTON, M.E., and TWYNAM, D. 1999. The World Wide Fund for Nature Arctic Tourism Project. Journal of Sustainable Tourism 8(4):305-323.

MURPHY, P.E. 1985. Tourism: A community approach. New York: Methuen.

NAVEEN, R. 1999. Visitor landings in the Antarctic Peninsula 1989-1999. Chevy Chase, Maryland: Oceanites, Inc.
NEWTON, S.T., FAST, H., and HENLEY, T. 2002. Sustainable development for Canada's Arctic and Subarctic communities: A backcasting approach to Churchill, Manitoba. Arctic 55(3): 281-290.

NEW ZEALAND ANTARCTICPROGRAMME. 1991. Antarctica: Tourism. Christchurch: New Zealand Antarctic Programme.

NICKELS, S., MILNE, S., and WENZEL, G. 1991. Inuit perceptions of tourism development: The case of Clyde River, Baffin Island. Études Inuit Studies 15(1):157-169.

NIMON, A.J. 1997. Gentoo penguin (Pygoscelis papua) responses to tourists and other disturbances in Antarctica. $\mathrm{PhD}$ dissertation, University of Cambridge, Cambridge, England.

NIMON, A.J., and STONEHOUSE, B. 1995. Penguin responses to humans in Antarctica: Some issues and problems in determining disturbance caused by visitors. In: Dann, P., Norman, I., and Reilly, P., eds. The penguins: Ecology and management. Chipping Norton, United Kingdom: Surrey Beatty. 420-439.

NOTZKE, C. 1999. Indigenous tourism development in the Arctic. Annals of Tourism Research 26(1):55-76.

NUTTALL, M., and CALLAGHAN, T.V., eds. 2000. The Arctic: Environment, people, policy. Amsterdam: Harwood Academic Publishers.

PEARCE, P. 1989. Tourist development. 2nd ed. Harlow, United Kingdom: Longman Scientific and Technical.

RODGERS, J. 1996a. The northern tourism experience: 1994 domestic and inbound markets to Canada's North. Ottawa: Canadian Tourism Commission.

1996b. The northern tourism experience: Challenges and opportunities. Ottawa: Canadian Tourism Commission.

ROY-SOLE, M. 2005. Champion for change. Canadian Geographic May/June: 12.

SMITH, V.L., ed. 1989. Hosts and guests: The anthropology of tourism. Philadelphia: University of Pennsylvania Press.

, ed. 1994a. Special Issue - Antarctic tourism. Annals of Tourism Research 21(2):221-455.

- 1994b. A sustainable Antarctica: Science and tourism. Annals of Tourism Research 21(2):221-230.

SPLETTSTOESSER, J. 2000. IAATO's stewardship of the Antarctic environment: A history of tour operator's concern for a vulnerable part of the world. International Journal of Tourism Research 2:47-55.

STEEL, G.D., and KIRBY, V.G. 1997. Social sciences and the Antarctic. In: Fitzgerald, P., and Higham, T., eds. Antarctic science beyond 2000. Christchurch: Antarctica New Zealand.

STONEHOUSE, B., and CROSBIE, K. 1995. Tourism impacts and management in the Antarctic Peninsula area. In: Hall, C.M., and Johnston, M.E., eds. Polar tourism: Tourism in the Arctic and Antarctic regions. Chichester: John Wiley and Sons Ltd. 217-234.

TIMOTHY, D.J., and OLSEN, D.H. 2001. Challenges and opportunities of marginality in the Arctic: A case of tourism in Greenland. Tourism Recreation Research 49(4):299-308.

TRACEY, P.J. 2000. Managing Antarctic tourism. PhD dissertation, Institute of Antarctic and Southern Ocean Studies, University of Tasmania, Hobart, Australia.

VIKEN, A. 1998. Ethnic tourism: Which ethnicity? In: Johnston, M.E., Twynam, G.D., and Haider, W., eds. Shaping tomorrow's 
North: The role of tourism and recreation. Northern and Regional Studies Series 6. Thunder Bay: Lakehead University Centre for Northern Studies. 37-53.

VISIT NORWAY. 2004. www.visitnorway.com/. Accessed 9 April 2005.

WATT-CLOUTIER, S. 2000. Speech given on August 23, 2000. Silarjualiriniq 5:2-5.

WHITE, K.J. 1994. Tourism and the Antarctic economy. Annals of Tourism Research 21(2):245-268.
WOLFE-KEDDIE, J. 1993. Tourism in the Eastern Arctic: Coping with "dangerous children." Journal of Applied Recreation Research 18(2):143-162.

WOODLEY, A. 1994. Culture, perceptions and community-based tourism: The case of Baker Lake, Northwest Territories. Master of Arts thesis, University of Waterloo, Waterloo, Ontario, Canada. WORLD TOURISM ORGANIZATION. 2003. 1st International Conference on Climate Change and Tourism. Djerba, Tunisia, 9-11 April 2003.

WRIGHT, P., and McVETTY, D. 2000. Tourism planning in the Arctic Banks Island. Tourism Recreation Research 25(2): $15-26$. 